\title{
Millennium Development Goals: The profound research on the Progress of Universal Primary Education in Pakistan (2000-2015)
}

\author{
Mr. Mazhar Ali Siddiqui \\ Director General Planning Development \& Research, \\ School Education \& Literacy Department, \\ Government of Sindh Karachi, Pakistan \\ Dr. Hamzo Khan Tagar \\ Director Public Private Partnership Node, \\ School Education \& Literacy Department, \\ Government of Sindh, Karachi Pakistan.
}

\begin{abstract}
This paper has been written in context of millennium development goal 02 universal primary education for all context. Paper examines millennium development goals (MDGs) period performance with particularly focused on last 05 years performance with expenditure and progress nexus. The qualitative analysis concludes that allocation is increaser sufficiency but its time barred utilizations system with massive mismanagement, investment in security to fight with manic of terrorism and earth quick in norther area of the region hampered millennium development goals agenda at large. The major obstacles in the agenda are sorted out and by the qualitative study and conclude that these obstacles are still prevailing in the system not resolved properly and direly needed to readdress as a challenge before revised strategy of sustainable development goals (SDGs04) quality education for all in Pakistan. Weakened Governance Fragmentation Lack of Clarity in Inter-Tier Relationships Poor Quality of Teachers \& Managers Quality of curriculum, textbooks \& exams Low level of literacy Out of school children Dropout, In-adequate financing Gender Equity Poor monitoring \& evaluation Imbalance in primary, middle \& secondary schools inconvenient school locations.
\end{abstract}

Keywords: Millennium Development Goals (MDGs), Universal Primary Education, Literacy, Major obstacles, Sustainable Development Goals (SDGs).

\section{INTRODUCTION}

\section{Millennium Development's Planning and Its objectives}

The Millennium Development Goals (MDGs) are eight international development goals and 21 targets that were established following the Millennium Summit of the United Nations in 2000 in Dakar conference, following the adoption of the United Nations Millennium Declaration. All 189 United Nations member states at the time and at least 23 international organizations, committed to help achieve the following Millennium Development Goals by 2015.

1. To eradicate extreme poverty and hunger

2. To achieve universal primary education

3. To promote gender equality

4. To reduce child mortality

5. To improve maternal health

6. To combat HIV/AIDS, malaria, and other diseases

7. To ensure environmental sustainability

8. To develop a global partnership for development 


\section{Over all objectives of Millennium Development Goals}

- To develop a global partnership for development.

- Raising peoples' living levels, i.e. incomes and consumption, levels of food, medical services, and education through relevant growth processes.

- Creating conditions conducive to the growth of peoples' self-esteem through the establishment of social, political and economic systems and institutions which promote human dignity and respect.

- Increasing peoples' freedom to choose by enlarging the range of their choice variables, e.g. varieties of goods and services. [1]

\section{General Perceptions about Millennium Development Goals in Pakistan}

The intellectual leadership of Pakistan concludes that a lack of policy support by the government, improper implementation of millennium development goals (MDGs) its poor institutional analysis and improper justification behind the global strategy, and the difficulty or lack of measurements for some goals create confusions for success or failure of the agenda. Some of them have opinions that funding's for achieving the goals were insufficient, major amount of the country's income has been going for defense and debt return services and remaining chunk was invested in earthquake in northern area including Azad Kashmir and also to use in war against terrorism, mostly famed as Taliban in Pakistan, they are also located in upper area of the country. It is also evident that corrupt practice of public and private sector managers severely affected the agenda of universal primary education in the country. It also argued broadly that without assessing the capacities, needs and holistic approach, efforts to achieve each millennium development goal independently (MDGs) would have serious contradictions with each other. For instance, work to achieve goal 01 (poverty reduction) and goal 07 (environment) could have been counterproductive if done in isolation. The general analysis of the intellectual leadership of Pakistan in context of millennium development goals MDGs performance in last 15 years that it is not the worst performer, but it has also at no point taken the millennium development goals MDGs seriously enough to ensure that sustained and meaningful progress has occurred. Pakistan has managed some progress in some targets and indicators specific to each goal. But none of that progress has been adequate compared to the goals, nor is there independently verifiable data to back up the claims of progress made by the government. The reasons are not hard to fathom: no overhaul of the bureaucracy or administration that must help achieve the goals; no restructuring of the state`s finances to free up money for investments in people centric development; no meaningful national conversation on what people-centric security really means. In the absence of any of that, it is impossible to imagine achieving universal primary education or ensuring environmental stability in the future. The public sector schools in Pakistan are producing time barred incompetent and unskilled youth in the global age of 21st century. In these yellow schools of government only child of urban labour / village farmers and lower middle class are enrolled in vast majority. This paper is also written to address above referred obstacles and to evaluate initiatives taken and progress in Pakistan education sector and to develop policy recommendation to support the international agenda of quality education for all in context of current issues in implementations in the greater public interest of Pakistani community.

\section{OBJECTIVES OF THE STUDY}

The specific objectives of the study were to:

i. A strategic review of Pakistan's performance in literacy during last 5 years of millennium development goals (MDGs).

ii. Assess how country has organized its educational activities in context of millennium development goals MDGs goal 02.

iii. Examine major obstacles in implementation of millennium development goals 02 ? 


\section{RESEARCH QUESTIONS}

The study was guided by the following questions:

i. what were the major obstacles in implementation of millennium development goals MDGs agenda in Pakistan's in context of educations for all goal 02 ?

ii. How have Pakistan acted against illiteracy and gender disparities?

iii. What is the result of last 05 years of MDGs strategy to bring universal primary education?

\section{SIGNIFICANCE OF THE STUDY}

The study proposes strategies that can be used by the policy makers and implementers to improve the ratio of enrollment and quality of education. Accordingly, the findings of the study can be used by the key players in this country to strengthen their respective roles for quality education.

\section{METHODOLOGY\& DATA}

The qualitative /descriptive statistics strategy has been adopted to identify empirical issues. Personal observations of the author as education expert, outcome of specific and target groups, primary and secondary data of some individuals and organizations have been used to strengthen the hypothesis. Evidences from Economic Survey of Pakistan, Secondary data of Federal Bureau of Statistics are also used. It's important to mentioned that data on enrollments in provinces of Pakistan in mostly discussed is based on [2] PSLM (2014-15) a reliable house hold survey Pakistan Bureau of statistics.

\section{DISCUSSIONS AND RESULT}

Universal Primary Education is the major social development incentive in Pakistan which is closely contacted with growth of the country in its inclusive strategy but not properly addressed by the elites of political economy. It is a universal fact that illiteracy generates religious intolerances, terrorism and unskilled low quality labour force and street crime at large. Several education policy and plans are prepared and implemented in the past in Pakistan but millennium development goals plan has major focus on literacy as its universal primary education for all as goal 02. Pakistan introduced Education Sector reforms and implemented Nation Plan of Action for EFA in the beginning of new millennium, Financial requirements had been worked out and despite of economic and financial constraints sufficient funds were provided but loopholes are not fulfilled and literacy profile of the country has raised serious question on 15 years progress of goal 02 . When we analyzed that data on literacy its $58 \%$ in 18 years of 21 th century. The rural and gender disparities are also showing alarming situation. It is evident that integrated approach has been adopted to address the issues of education sector development from all dimensions. However effective monitoring system has not been placed to assure efficiency and achievements due to political ill will and bureaucratic red-tapes. The main reason for the poor progress of millennium development goals (MDGs) is investment of the national resources against religious terrorisms in upper region and its impact on the entire country economy after tragedy of $9 / 11 / 2000$. The increase in enrolment, provision of quality teachers, reduce rate of dropout, renewed commitment to focus more on is still the prevailing challenges. The similar goals are again focused in second revised strategy of sustainable development goals (SDGs). The proposed 17 targets are ambitious in terms of their universality but will be difficult to achieve without progress in quality education and literacy front. 


\section{An overview of the last Phase of Universal Primer Education Agenda 02 of MDGs}

It is evident on the basis of (PSLM) house hold survey that, the Gross Enrolment Ratio (GER) for primary schools in Pakistan (Age 6-10) at National level has decreased 1 percent despite increase more, its 91 percent in 2014-15 from 92 percent in 2012-13. Above survey indicates that all provinces have shown same trend however, the decrease in overall Pakistan is due to decline in Sindh to 79 percent in 2014-15 from 81 percent in 2012-13. Sindh province decline literacy trends also affected national trends despite a fact that a powerful bureaucrat's part and parcel of ruling family of Pakistan People's Party was served in Sindh for the last 5 years as secretary education with full freedom to pick and choose. Survey further concludes that "Punjab with 98 percent has the highest in gross enrollment rate and Baluchistan with 73 percent has the lowest among the provinces. The net enrolment rate for primary schools (Age 6-10) at National level decreased to 67 percent in 2014-15 as compared to 68 percent in 201213. It remains substantially lower than the gross enrollment rate because of the enrolment of overage children. Punjab with 70 percent has the highest rate at primary level whereas Baluchistan with 56 percent has the lowest". (PSLM 2014-15). Survey bifurcated province wise highest and lowest trends in school educations these kinds of trends widen more disparities in trends of literacy, poverty and inequality among the provinces in the future in all areas of economic growth and social development of the regions. The situation will not be favorable and will create more complex satiations in implementations of sustainable development goals a revised and extended global agenda of sustainable development. The literacy rate of population (10 years \& above) at National level remains stagnant at 60 percent during the period 2014-15 and 2012-13. Literacy remains much higher in urban areas than in rural areas and much higher in men than in women. Adult literacy rate (15 years \& above) at National level also remains stagnant at 57 percent during the period 2014-15 and 2012-13. The gap between given targets and achievements in net primary enrolments is $43 \%$, literacy gap in overall country is $28 \%$, gender parity index at primary and secondary level is also unachieved including youth literacy in the country which is also missing from the target. The table 1 shows 5 years data of Pakistan literacy indicators from 2010-11 to 2014-15 and targets of last years of millennium development goals MDGs. the base year of data is 1991.The Net primary enrollment increase is only $1 \%$ as mentioned in column 1 the increase is only from $56 \%$ to $57 \%$. Overall increase in literacy is only $2 \%$ from $58 \%$ to $60 \%$ in last 5 years which is not up to mark comparison of huge expenditure on education and literacy. It is also a fact that our policy makers/elites i.e. politician's, feudal, bureaucrats, defense leaders' judges, national level journals, spirituals leaders and business tycoons are not real stake holder of public sector educations of Pakistan their generations are enrolled in urban centers privately owned grammars schools and then foreign universities mostly UK and USA universities and schools. so that that their area of interests is very limited to bring change in the system. 
Table -1 Last Five Years Educational Performance Indictors' in Pakistan in Context of MDGs

\begin{tabular}{|l|c|c|c|c|c|c|c|}
\hline $\begin{array}{l}\text { Performance } \\
\text { Indicator }\end{array}$ & $\begin{array}{c}\text { Base Year } \\
1991\end{array}$ & $2010-11$ & $2011-12$ & $2012-13$ & $2013-14$ & $\begin{array}{c}\text { 2014-15 } \\
\text { (Achievement) }\end{array}$ & $\begin{array}{c}\text { MDGs } \\
\text { Targets }\end{array}$ \\
\hline $\begin{array}{l}\text { Net Primary } \\
\text { Enrolment } \\
\text { Ratio }\end{array}$ & 46 & 56 & 57 & 57 & 57 & 57 & 100 \\
\hline Literacy Rate & 35 & 58 & 58 & 60 & 58 & 60 & 88 \\
\hline $\begin{array}{l}\text { Gender Parity } \\
\begin{array}{l}\text { Index for } \\
\text { Primary } \\
\text { Education }\end{array}\end{array}$ & 0.73 & 0.88 & 0.90 & 0.89 & 0.88 & 0.88 & 01 \\
\hline $\begin{array}{l}\text { Gender Parity } \\
\text { Index for } \\
\text { Secondary } \\
\text { Education }\end{array}$ & -- & 0.85 & 0.81 & 0.89 & 0.84 & 0.87 & 0.94 \\
\hline $\begin{array}{l}\text { Youth } \\
\text { Literacy Rate }\end{array}$ & 0.51 & 0.79 & 0.81 & 0.82 & 0.80 & 0.82 & 01 \\
\hline
\end{tabular}

[2]

The expenditure statement given below is 05 years expenditure of education sector of Pakistan including higher and technical education as national expenditure a on education. The allocation of funds is increased from $1.8 \%$ of GDP to $2.2 \%$ in last 5 years, the current year expenditure is 598 billion, but increase in universal primary education is only $2 \%$ in overall enrollment. The million dollars question is where this huge flow of money goes. There is neither improvement in quantity nor in quality of education in greater public interest.

This is also important to mentioned that in last 05 years sufficient funds are allocated for development of infrastructure in education sector as mentioned in table 02 but real picture of the educational infrastructure in schools is very poor and far from reality. It is clear mismanagement in the public funds at large by the elites of the country with their mutual understandings for their luxurious life and their children education abroad on public cost.

Table -2 Five Years Expenditure on Education sector in Pakistan (Rs in thousand million)

\begin{tabular}{|c|c|c|c|c|c|}
\hline S. No & Year & $\begin{array}{c}\text { Current } \\
\text { Expenditure }\end{array}$ & $\begin{array}{c}\text { Development } \\
\text { Expenditure }\end{array}$ & $\begin{array}{c}\text { Total } \\
\text { Expenditure }\end{array}$ & $\begin{array}{c}\text { As \% Percentage } \\
\text { Of GDP }\end{array}$ \\
\hline 1 & $2010-11$ & 276,239 & 46,572 & 322,812 & 1.8 \\
\hline 2 & $2011-12$ & 330,228 & 63,295 & 393,523 & 2.0 \\
\hline 3 & $2012-13$ & 428,944 & 50,909 & 479,853 & 2.1 \\
\hline 4 & $2013-14$ & 453,735 & 83,863 & 537,598 & 2.1 \\
\hline 5 & $2014-15$ & 499,982 & 98,333 & 598,315 & 2.2 \\
\hline
\end{tabular}

[3]

The increase in enrolment and net literacy needed good infrastructure for educations which attracts more the student and their parents to enroll in public sector schools for wellbeing in education. The data for out of schools is varies from time to time and from province to institutions responsible e for data collection but estimated data of out of school's children are 22 million out of 200 million populations of Pakistan. The reason behind major cause is child's labour and chronic poverty in the country others reasons is unavailability of schools and poor infrastructures absent teachers and others. The poor infrastructures and its decreased allocation for development is caused by the increase in salary expenditure as reflected in table 03 and 04. 
Table -3 Province Wise Salary Expenditure of Education Sector

\begin{tabular}{|l|c|c|c|c|c|}
\hline & & & & & \\
Province & FY2010 & FY2011 & FY2012 & FY2013 & FY2014 \\
\hline Baluchistan & $106 \%$ & $108 \%$ & $120 \%$ & $124 \%$ & $107 \%$ \\
\hline KP & $100 \%$ & $100 \%$ & $105 \%$ & $102 \%$ & $97 \%$ \\
\hline Punjab & $93 \%$ & $91 \%$ & $96 \%$ & $92 \%$ & $\mathbf{8 7 \%}$ \\
\hline Sindh & $76 \%$ & $131 \%$ & $103 \%$ & $\mathbf{9 2 \%}$ & $\mathbf{9 1 \%}$ \\
\hline
\end{tabular}

[4]

Table-4 Development Expenditure as Percent of Total Education Expenditure 2010-14

\begin{tabular}{|l|l|c|}
\hline \multicolumn{1}{|c|}{ PY 2010 } & FY 2014 \\
\hline Baluchistan & $13 \%$ & $\mathbf{9 \%}$ \\
\hline Khyber-Pakhtunkhwa & $\mathbf{3 \%}$ & $\mathbf{7 \%}$ \\
\hline Punjab & $10 \%$ & $\mathbf{1 0 \%}$ \\
\hline Sindh & $\mathbf{4 2 \%}$ & $\mathbf{1 1 \%}$ \\
\hline
\end{tabular}

[4]

The (PSLM) Data of 2014-15 further indicates that he overall share has decreased to 62 percent in 2014-15 as compared to 66 percent in 2012-13. The GER for middle level (Age 1113) at National level decreased to 62 percent in 2014-15 as compared to 63 percent in 201213. Province wise Gross Enrollment Rate at middle level shows that Punjab and Sindh decreased to 64 percent and 55 percent in 2014-15 as compared to 65 percent and 57 percent in 2012-13 respectively, whereas there is increasing trend in Khyber Pakhtunkhwa with 71 percent in 2014-15 as compared to 69 percent in 2012-13, and Baluchistan province remains stagnant at 65 percent during the period 2014-15 and 2012-13. However, NER (Age 11-13) which gives more realistic picture decreased to 37 percent in 2014-15 as compared to 38 percent in 2012-13 in the country[2]

The significant decreeing trends are $4 \%$ in primary, $1 \%$ in middles schools, Baluchistan is at cross the road and KPK is in progressive path in comparison of the provinces of Pakistan. The Matric level GER (Age 14-15) for National level has slightly increased to 58 percent in 2014-15 as compared to 57 percent in 2012-13. Punjab with 63 percent and Baluchistan with 39 percent are at highest and lowest respectively. NER at National level increased slightly to 27 percent in 2014-15 from 26 percent in 2012-13. [2]

Nadia Naveen (2016 pp10) a Woodrow Willison Scholar concludes that Pakistan's education challenge is not underspending. It is misspending. Without reforms, new money is likely to end up feeding cronyism and corruption, rather than making a difference that children can feel. A former education secretary for Sindh sums up the situation: "The existing budget has huge leakages. The school construction and the repair and maintenance contracts, like other construction works contracts, are commission-based. Fixed commissions [kickbacks] to the engineer and government departments for construction work are as high as 40 percent. Contracts for construction schemes are largely influenced by political representatives".[4]

It is evident that development allocation spending has increasing trends in the last phase of MDGs (2010 -2015) from 43 to 107 and from 36 to 90 percent but progress in term s of literacy is inversely related with development funds utilization as reflected in table 5 and 6 respectively. 
Table -5 Year wise Development Budget Utilization Rate\%

\begin{tabular}{|l|c|c|c|c|c|c|}
\hline \multicolumn{2}{|l|}{$\begin{array}{l}\text { Province } \\
\text { FY2010 }\end{array}$} & FY2011 & FY2012 & FY2013 & FY2014 & FY2015 \\
\hline $\begin{array}{l}\text { Baluchi } \\
\text { stan }\end{array}$ & $\mathbf{4 3 \%}$ & $\mathbf{7 8 \%}$ & $\mathbf{8 2 \%}$ & $\mathbf{5 2 \%}$ & $\mathbf{6 4 \%}$ & $\mathbf{1 0 7 \%}$ \\
\hline KP & $\mathbf{8 8 \%}$ & $\mathbf{9 3 \%}$ & $\mathbf{7 2 \%}$ & $\mathbf{5 0 \%}$ & $\mathbf{9 7 \%}$ & $\mathbf{7 8 \%}$ \\
\hline Punjab & $\mathbf{5 8 \%}$ & $\mathbf{8 5 \%}$ & $\mathbf{2 3 \%}$ & $\mathbf{8 9 \%}$ & $\mathbf{4 6 \%}$ & $\mathbf{4 5 \%}$ \\
\hline Sindh & $\mathbf{3 6 \%}$ & $\mathbf{6 \%}$ & $\mathbf{4 1 \%}$ & $\mathbf{3 3 \%}$ & $\mathbf{5 8 \%}$ & $\mathbf{9 0 \%}$ \\
\hline
\end{tabular}

Data Source [4]

A World Bank study reveals that major cause of lower trends in literacy is enrolment in low cost or no cost religious madrassah's "Pakistan and Nigeria, which have the highest number out of school children in the world, are outliers among countries because so many students opt for low-cost private schools. Private expenditure is not included in international comparisons because it is difficult to track". [5]

Sindh decreased 01\%, Baluchistan and Punjab increase $0 \%$ and overall increase in Khaber Paktuon Khwa (KPK) is $07 \%$ in last five years, despite utilization of hundred billion rupees for increase in literacy in the country as mentioned in table 6. The data mentioned below suggest to revisit the agenda to formulate coherent development strategy to bring quality education for all in Pakistan.

Table -6 Change in Primary Net Enrollment Rates for 6-10 Year Olds since 2010 - 2015

\begin{tabular}{|l|c|c|c|c|}
\hline $\begin{array}{l}\text { Province } \\
\text { 2010/11 }\end{array}$ & $2014 / 15$ & Change \\
\hline Baluchistan & $56 \%$ & $56 \%$ & 0 \\
\hline KP & $64 \%$ & $71 \%$ & $07 \%$ increase \\
\hline Punjab & $\mathbf{7 0 \%}$ & $\mathbf{7 0 \%}$ & $\mathbf{0}$ \\
\hline Sindh & $\mathbf{6 2 \%}$ & $\mathbf{6 1 \%}$ & $\mathbf{1 \%}$ decrease \\
\hline
\end{tabular}

Data Source [4]

\section{CONCLUSION}

It is concluded that the below listed major obstacles are prevailing in the system not resolved with due diligences and still pose a challenge in revised strategy of sustainable development goals (SDGs 04) quality education for all in Pakistan. Weakened Governance, Fragmentation, Lack of Clarity in Inter-Tier Relationships Poor Quality of Teachers \& Managers, sub slandered quality of curriculum, textbooks \& exams, Low level of literacy of parents/communities, Out of school children because of child labor high ratio of Dropouts due to $p$, In-adequate and untimely financing Gender disrcrmentions Poor monitoring \& evaluation of school and infrastructural development schemes, Imbalance in primary, middle \& secondary schools Inconvenient school location.

Pakistan is a country of vast resources potential in lower middle-income economies but its time barred system is hosted by the bad governance element mostly cladded vested interest i.e. bureaucracy, political ill wills and teacher's union and corrupt practices at all levels. Pakistan's policy makers and implementers are not the real stake holders of the public sector education and depends on private sector schools situated in posh area of urban centers or at abroad to enroll their kids in schools. It is concluded that government of Pakistan and international donners organization plans; policies and programs are theoretically well and colorful but in implementations not feasible and result ordinated at large. Several efforts have been taken to create a literate society by accelerating development process with allocating more financial 
resources for capacity building, research \& development but outcome is still unsatisfactory as discussed above in last table of progress of literacy among four provinces.

The provision of education access to lower and lower middle-income households' children, to decreased disparity among various region races and tribe, increased quality to strengthen retention and decrease dropout rate at all levels needed coherent development planning strategy to cope the challenge of universal primary education/literacy in context of growth literacy nexus with quite support of development planning professional and educational experts to formulate and implement the current agenda of sustainable development goals in light of the lesson learnt during millennium development goals Period 2001-2015.

For improving access, equity and quality education, investment is direly needed in the physical infrastructure, capacity building and assurance of teacher's attendance, up-gradation of educational institutions and opening of new educational facilities for boys and girls in far flung locations rural and arid regions is needed revised coherent development planning to provide quality education for all in context of sustainable development goal 04 .

\section{References}

UNDP (2015): The Millennium Development Goals, Report.

Pakistan Social and Living Standards Measurement Survey (P S L M 2014-15) National / Provincial /District government Of Pakistan Statistics Division Pakistan Bureau of Statistics Islamabad. Www.Pbs.Gov.Pk

Pakistan Government of (2016), Economic Survey of Pakistan. Islamabad, Ministry Of Finance \& Economic Affairs Division. Pp.2, 13, 20, 21, 23.

Nadia Naveen 2016 "Pakistan's Education Crisis: The Real Story" Woodrow Wilson International Center for Scholars One Woodrow Wilson Plaza 1300 Pennsylvania Avenue NW Washington, D.C. 200043027.www.wilsoncenter.org

Saavedra, Jorge (2002), Education Financing in Developing Countries: Levels and Sources of Funds World Bank Institute: http://info.worldbank.org. 